\title{
Tree Wound Responses Following Systemic Insecticide Trunk Injection Treatments in Green Ash (Fraxinus pennsyl- vanica Marsh.) as Determined by Destructive Autopsy
}

\author{
Joseph J. Doccola, David R. Smitley, Terrance W. Davis, John J. Aiken, and Peter M. Wild
}

\begin{abstract}
Trunk injection of systemic insecticides or fungicides is an effective way to manage destructive insects or diseases of trees, but many arborists are still reluctant to inject trees because of the potential for infection by pathogens, structural damage, or adverse effects on tree health. The authors of the following study examined wound responses of green ash (Fraxinus pennsylvanica Marsh.) for two years following trunk injection, by sectioning tree trunks to look for evidence of infection associated with injection sites, and by collecting data on annual radial growth and rate of closure around injection sites. All healthy trees successfully compartmentalized injection wounds without any signs of infection, decay, or structural damage. Wound closure was positively correlated with the tree health as measured by annual radial growth.

Key Words. Canopy Dieback; Decline; Emerald Ash Borer; Stem Injection; Systemic Insecticide; Tree Health; Wound Closure; Woundwood.
\end{abstract}

The recent discovery that trunk injections of emamectin benzoate will provide 2-4 years of complete protection from emerald ash borer (EAB, Agrilus planipennis Fairmaire) has led to a dramatic increase in the number of trunk-injected trees in the Midwest United States (Smitley et al. 2010). With trunk injections becoming a standard practice for arborists, more information is needed on the long-term injury (i.e., two or more years) caused by trunk injections (Smith 1988). The mechanical wound made during injection is generally small but it could provide an entry point for pathogens, and the injected product (active ingredient + formulation) or the pressure applied during the injection process may injure cambial tissues (Shigo et al. 1977). Unfortunately, most publications on trunk injections focus on efficacy of the injected pesticide and rarely include an evaluation of the injury caused by the injections or how quickly trees recover from the injury (Chaney 1986; Ellmore et al. 1988; Tattar and Tattar 1999; Sanchez-Zamora and FernandezEscobar 2004; Dujesiefken et al. 2005; Smith and Lewis 2005).

Fraxinus trees are ring porous (Salisbury and Parke 1970; Esau 1977), with the early wood vessels being larger and more visible than late wood vessels which are too small to be seen with the naked eye. Fraxinus trees also have broad conducting sapwood compared with many other tree species, like Ulmus, and Quercus (Shigo 1991). Trees are highly compartmented plants with each annual ring of radial growth forming a compartment (Shigo 1984). Trees have evolved a strategy of growing around traumatized tissue rather than expending energy to repair wounds. The compartmentalization process may be divided into two stages: reaction zones set up at the time of trauma in existing wood and responses (i.e., growth) that occur after trauma (Smith 2006). After a tree is wounded, the lateral cambium divides to form new tissue that grows over the injury. This tissue is called the barrier zone. Barrier zones resist the outward spread of decay. A model describing the biochemical and anatomical process of wound response in trees was developed by Shigo and Marx (1977). Individual trees may vary considerably in the strength of their response to same type of wound depending on genetics or tree health (Shigo 1999).

In this study, the advancing wave of EAB was taken advantage of (Haack et al. 2002; McCullough et al. 2003; McFarlane and Meyer 2003; Cappaert et al. 2005; Herms et al. 2009), along with the subsequent decline and death of green ash street trees in East Lansing, Michigan, U.S., to see how green ash trees in various states of health responded to wounding caused by standard trunk injection treatments.

\section{MATERIALS AND METHODS}

The purpose of this study was to determine how healthy and compromised green ash trees respond to wounds caused by standard trunk injection treatments. As EAB swept through East Lansing between 2005 and 2009, trees declined rapidly from an extremely heavy borer infestation ( $>50$ larvae $/ \mathrm{m}^{2}$ ), resulting in the death of all unprotected trees by 2009 , while trees receiving effective insecticide treatments remained healthy (Figure 1a; Figure 1b; Smitley et al. 2010). Because the city of East Lansing was in the process of removing all of their green ash street trees due to the devastation caused by EAB, the study authors were allowed to cut and examine trees before they were removed. In order to observe the response of healthy and weakened trees to wounds created by insecticide injection, two green ash trees were randomly selected from each of seven trunk-injection treatments 
that were part of a larger study. The seven insecticide treatments were chosen to represent a range of efficacy based on the active ingredient and year the insecticide was injected in relationship to the borer infestation (Smitley et al. 2010; Table 1). Trees that appeared to have a flat or sunken area of the lower trunk due to a previous injury or infection were excluded from this study. Selected trees ranged from 21.5 to $36.3 \mathrm{~cm}$ dbh (mean $=27.6$ $\mathrm{cm}$ ) and were located between the street and the sidewalk in one of seven different neighborhoods. All trees were healthy at the beginning of the study $(<25 \%$ canopy thinning).

Annual canopy thinning and dieback ratings were made in July of each year by comparing the canopy of each tree with photographs in various stages of decline from $0 \%$ (healthy) to $100 \%$ (dead) in 10\% increments (Smitley et al. 2008). Each tree was rated by two or three individuals and averaged across observations to obtain an annual rating.

Insecticides placed into green ash trees by trunk injection or by implantation were: emamectin benzoate (TREE-äge, 0.04 g/g ME, Syngenta Crop Protection, Greensboro, NC, U.S.), imidacloprid (0.05 g/g SL, IMA-jet, Arborjet, Inc., Woburn, MA, U.S.), imidacloprid (0.20 g/g SL, MERIT Tree Injection, Bayer Crop Science, Clayton, NC, U.S.), and acephate (ACECAP 97S, 0.97 g/g, Creative Sales, Fremont, NE, U.S.). Products were injected per label instructions as diluted with water or neat (nondiluted). Treatments were applied using no pressure (i.e., implants only), low pressure (310 kPa) micro- infusion $^{\mathrm{TM}}$, or high pressure (1379 $\left.\mathrm{kPa}\right)$ micro-injections. Drill holes varied in diameter, depth, frequency and location on the stem based on the specific method of application used.

For the ACECAP 97 (acephate) treatment a $9 \mathrm{~mm}$ diameter drill bit was used to drill $3.2 \mathrm{~cm}$ deep into the sapwood. Holes were drilled $10 \mathrm{~cm}$ apart on the stem spiraling up and around the trunk from the base of the tree, until the correct number of holes (i.e., seven or eight per tree) was drilled according to the label. Two trees were treated with acephate implants on May 16, 2006, at a rate of $0.60 \mathrm{~g} \mathrm{AI} / 2.54 \mathrm{~cm}$.

The four trees trunk-injected with TREE-äge (emamectin benzoate), were injected by low pressure micro-infusion ${ }^{\mathrm{TM}}$. These injections were made by drilling four injection ports with a 7 $\mathrm{mm}$ diameter drill bit. Holes were drilled perpendicular to the trunk and were located 15 to $20 \mathrm{~cm}$ apart on the trunk circumference at a height of $20-40 \mathrm{~cm}$ above the ground. Plastic septums (Arborjet \#3 Arborplug) were tapped into the drilled holes and the ports connected with plastic tubing to a single pressurized $310 \mathrm{kPa}$ bottle containing TREE-äge diluted 1:1 with water. The TREE-äge solution was injected at a rate of $0.4 \mathrm{~g} \mathrm{AI} / 2.54 \mathrm{~cm}$ DBH on September 27, 2005. No additional treatments were made to two of the four trees for the duration of the test. The two remaining trees were re-treated on May 21, 2008 with TREEäge using the same apparatus and rate but drill holes were larger (9 $\mathrm{mm}$ diameter). Repeat injections were staggered from the original injection sites a minimum of $5 \mathrm{~cm}$ whenever possible.

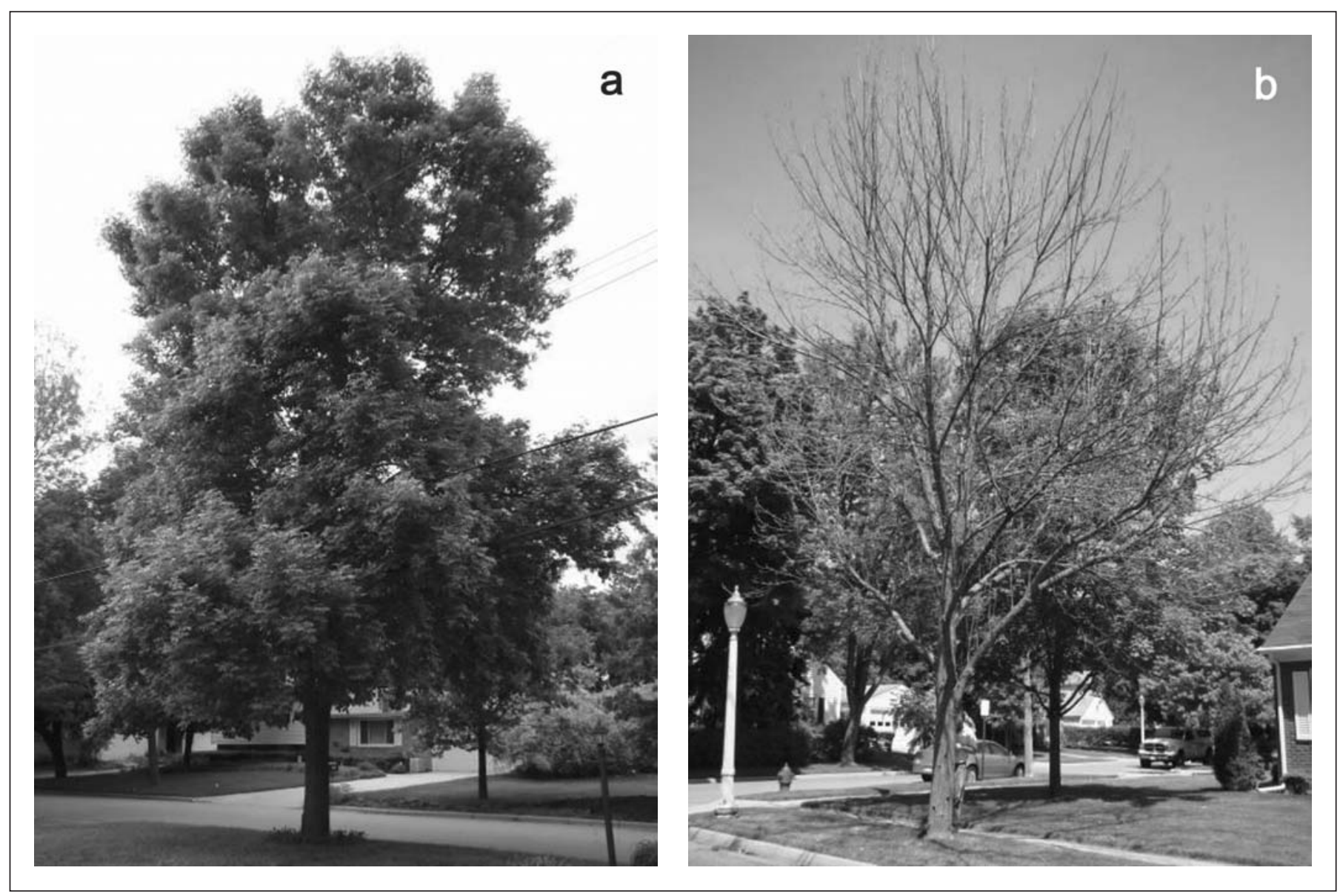

Figure 1. Green ash street trees in East Lansing, Michigan in August 2009 just before trees were felled for this study: a) tree receiving TREE-äge trunk injections in fall 2005; b) control tree. 
IMA-jet (5\% imidacloprid) was micro-infused into two trees on September 29, 2005. Two more trees received the same microinfusion treatment on May 21, 2008. All four trees received 0.4 $\mathrm{g} \mathrm{AI} / 2.54 \mathrm{~cm} \mathrm{DBH}$. A second product containing imidacloprid, Merit Tree Injection (200 SL, $200 \mathrm{~g}$ ai/l), was injected into two trees on October 17, 2005, and two more trees on May 21, 2008. Injections were made with the Arborjet Air Hydraulic Device at a rate of $0.4 \mathrm{~g} \mathrm{AI} / 2.54 \mathrm{~cm} \mathrm{DBH}$. Each injection was made through a plastic septum (7 mm diameter, \#3 Arborplug) at $1379 \mathrm{kPa}$.

Two untreated control trees were included in the study for the purpose of collecting data on the growth rates of trees severely compromised by EAB. Water-injected controls were not included in this study because the study authors anticipated that all trees that were not treated with insecticide would decline rapidly due to EAB and would not yield any useful data to compare with insecticide-injected trees.

All 16 trees (14 trunk-injected and two untreated control trees) were felled in July 2009 by cutting the trunks at a height of $1.5 \mathrm{~m}$ above the ground, and again at ground level. The 1.5 $\mathrm{m}$ trunk bolts were transported to the Michigan State University Entomology Research Farm in East Lansing, where cross-sections and longitudinal-sections were cut to facilitate measurement of annual radial growth, area of vascular discoloration, area of wounding due to trunk injection, and annual closure of wounds from new growth of vascular tissue and woundwood. This was done by cutting the bolts again at $15 \mathrm{~cm}$ and $60 \mathrm{~cm}$ above and $15 \mathrm{~cm}$ below the injection sites. Each cut disc was planed (Dewalt model \# DW680) smooth and photographed in transverse section. The age of the trees was determined by counting the number of growth increments from the pith to the most current growth ring. These sections were then quartered with a log splitter (Huskee 34 ton log splitter). Each quarter section was then cut through the injection site using a table saw (Craftsman $25 \mathrm{~cm}$ table saw with a Freud Avanti Tico high density carbide blade) and Ryobi miter saw (25 cm Skil 60-tooth crosscut blade). Digital photos were taken of each radial section. Calculations for wound closure were based on the area of an ellipse $\left(\varpi r_{1} r_{2}\right)$, where $r_{1}$ equals the radius of cambium injured and $r_{2}$, the radius of the circumferential discoloration measured. The percent area of wound closure was calculated for each growing year following injection using the formula $\mathrm{cm}^{2}$ of new vascular tissue $/ \mathrm{cm}^{2}$ of injured lateral cambium. Radial sapwood growth was measured by micrometer (Model No. CD-6"GS, Mitsutoyo Corp., Japan) for two years prior to and the two years after the injection holes were made.

\section{Data Analysis}

The closure of wounds around each of four or five trunk injection sites per tree was measured each year. Percent wound closure was then determined based on the size of the original wound. Data for the four or five injection sites per tree were then averaged to give mean values for each tree. Because the 14 study trees were injected in different years, annual ring growth and wound closure data were recorded and analyzed in relation to the year of trunk injection. Year 1 or Year 2 refer to the amount of annual ring growth and wound closure occurring in the first or second (respectively) growing season following autumn or spring trunk injections. Therefore, for trunk injections made in October 2005 and in May 2006, ring growth and wound response in Year 1 were determined by tree growth in spring, summer, and autumn 2006; and ring growth and wound response in Year 2 were determined by tree growth in spring, summer, and autumn 2007. The relationship of canopy thinning and dieback to ring growth in the same year was determined by regression analysis. Percent data were arcsine transformed using the formula: $\arcsin (\mathrm{sqrt}(\mathrm{x} / 100)$, prior to analysis. Graphs of these relationships were made using nontransformed percent data. The polynomial regression for the relationship of annual ring growth to canopy thinning and dieback ratings was made using StatView (Abacus Concepts 1992). Linear regressions for the relationships of annual ring growth to canopy thinning, and for annual ring growth to percent wound closure, were made using SuperAnova (Abacus Concepts 1991).

\section{RESULTS}

All 16 study trees were felled and sectioned in July 2009, 1.1 to 3.8 years following trunk injection treatments. Mean DBH of the felled green ash trees in this study was $27.6 \mathrm{~cm}$, and ranged from 18.8 to $36.3 \mathrm{~cm}$. Growth-ring counts indicated that the trees ranged from 17- to 35-years-old (mean age 26.3). A total sixtythree trunk injection wound sites were evaluated by sectioning trunk bolts through the drilled injection holes, which were 16to 52-mm-deep. No signs of cracking, oozing, or decayed tissues were found associated with any of the 63 injection sites. A total of $76.2 \%$ of the injection sites were completely closed by new wound growth, $12.7 \%$ of the injection sites were closed except the presence of a partially extruded plug, and $11.1 \%$ of the injection sites did not completely close. Discolored areas associated with the injection sites were still visible four years after the injections were made, but the discolored areas were firm with no signs of infection or deterioration (Figure 2).

Ring growth measurements indicate that two trees (tree \#1 and tree \#2) increased their growth rates in the first or second year after trunk injection, while eight trees continued to grow at a similar rate, and four trees decreased their growth rate in the first or second year after trunk injection (trees \#6, \#10, \#11, and $\# 12$; Table 1). Regression analysis indicates that ring growth was strongly dependent on the level of EAB infestation as measured by canopy thinning and dieback ratings in July of the same year (Figure 3). EAB larvae actively tunnel in the cambial tissue from August to October. Therefore, canopy ratings in July reflect the amount of injury caused by EAB the previous autumn. Although many other factors can cause the same canopy thinning and dieback symptoms, in this case the study authors knew the dieback was caused by EAB because of a more extensive study being conducted at the same time in the same neighborhoods. In that study, 19 of the green ash street trees that were trunk injected with emamectin benzoate, the most effective insecticide treatment, had a mean canopy thinning and dieback rating of $13.5 \pm$ $14.1 \%$ in July of 2009 , compared with a rating of $58.1 \pm 33.2 \%$ in July of 2009 for 10 untreated control trees (Smitley et al. 2010). Branch samples from the same trees revealed that the emamectin-injected trees had no detectable EAB larvae, while the control trees averaged an infestation level of $28.7 \pm 21.5$ (mean \pm SD) EAB larvae per $\mathrm{m}^{2}$ (Smitley et al. 2010). It can therefore be concluded that extensive canopy thinning and dieback caused by EAB resulted in a reduced rate of radial ring growth (width) in unprotected green ash trees. Regression analysis of this relationship indicates $53 \%$ of the variation in ring width can be 

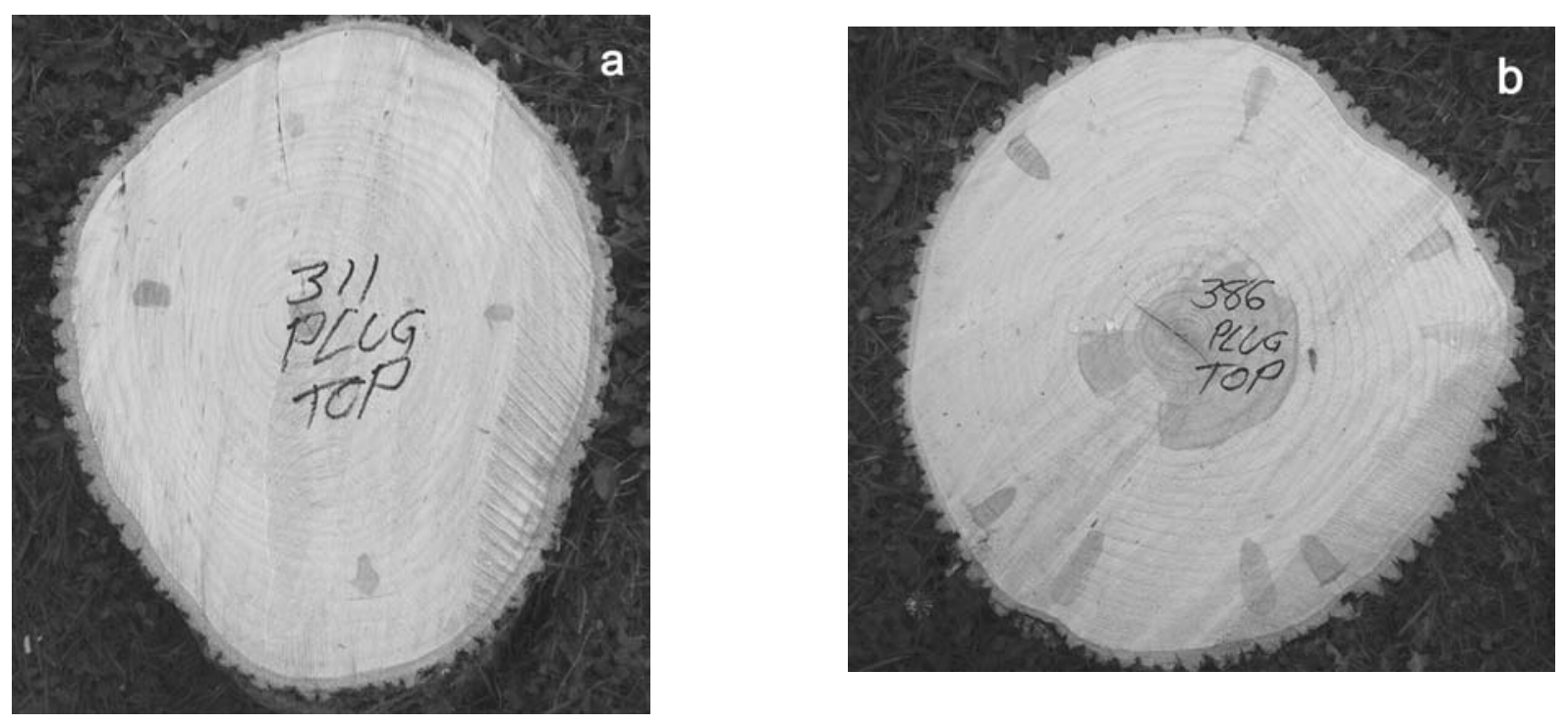

Figure 2. Cross-sections of tree trunks cut just below the injection sites. a) Trunk injections to this tree were made in autumn 2005 only, four injection sites with TREE-äge. b) Trunk injections to this tree were made in autumn 2006 and again in spring 2008, four injection sites per treatment. Discoloration columns due to trunk injections are still visible but there is no evidence of decay.

explained by the canopy thinning and dieback ratings made in July of the same year. As the level of canopy thinning and dieback increases from $0 \%$ to $100 \%$, radial ring growth decreases from $0.5 \mathrm{~cm}$ to $0.05 \mathrm{~cm}$ (Figure 3). The regression model for a linear fit is $\mathrm{y}=0.32-3.85 \mathrm{e}-3 \mathrm{x}$, where $\mathrm{y}=$ radial ring width and $\mathrm{x}=\%$ dieback $\left(\mathrm{n}=16, \mathrm{~F}=16.9, \mathrm{P}<0.001, \mathrm{r}^{2}=0.53\right)$.

Differences in the rate of wound closure were dependent on tree growth rates in the same year (Figure 3). Healthy trees with little canopy thinning and dieback $(<15 \%)$, and with ring widths similar to or greater than their width before trunk injection, rapidly grew over trunk injection wounds with no signs of infection or structural damage, while trees heavily infested with EAB and with reduced growth widths did not close injection wounds as rapidly. At the end of the first growing season following trunk injection treatments, $63 \%$ of the variation in percent wound closure at that time can be explained by the amount of radial ring growth in the same growing season. The linear regression model expressing the relationship between percent wound closure and ring growth is $\mathrm{y}=51.8 \mathrm{x}+6.22\left(\mathrm{n}=14, \mathrm{~F}=20.5, \mathrm{P}<0.001, \mathrm{r}^{2}=0.63\right)$. Percent wound closure continued to be dependent on ring growth in the second year following trunk injections as well. The linear relationship between wound closure and ring growth in Year 2 can be expressed as $\mathrm{y}=44.1 \mathrm{x}+45.9\left(\mathrm{n}=14, \mathrm{~F}=20.5, \mathrm{P}<0.001, \mathrm{r}^{2}=0.63\right)$.

\section{CONCLUSIONS AND DISCUSSION}

Data collected from felling, sectioning and examining vascular tissue around 63 injection sites in 14 trees gives no indication of any compromise in structural integrity, no signs of infection, and no indication of negative impacts on tree health due to trunk injection of insecticides. The two untreated trees felled and examined in this study were not injured by drilling and plugging as were the 14 systemically treated green ash; comparisons of wound closure responses therefore were not made (Table 1). Trees responded rapidly to the injection wounds, growing over $80 \%$ of the injured vascular surface area in two years, regardless of insecticide treatment. The only trees not recovering rapidly from injection wounds were two trees that were seriously compromised by emerald ash borer injury (Figure 4). Regression analysis suggests that wound closure rates are strongly dependent on tree health as expressed by ring growth.

Healthy trees successfully compartmentalized injection wounds without any signs of infection, decay, or structural damage (Figure 5a). The vascular growth rates for healthy trees during a two-year period following trunk injections were similar to or greater than the growth rates before trunk injections. Tree growth after injection resulted in the rapid closure of wounds without any detectable adverse affects on tree health or structure. In $13 \%$

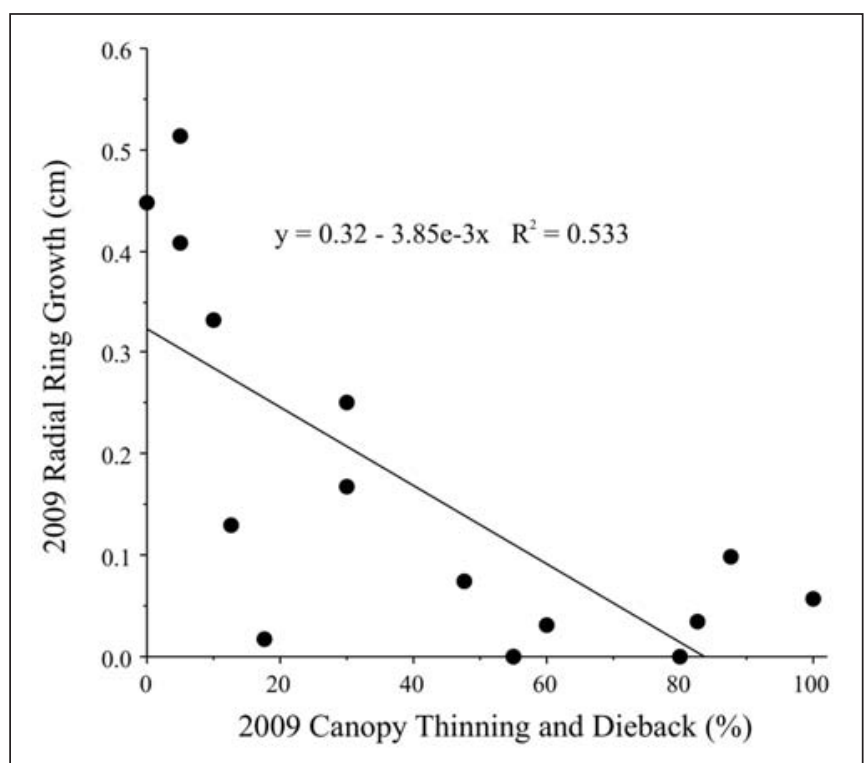

Figure 3. Relationship of the radial ring growth of 16 study trees in $\mathbf{2 0 0 9}$ to canopy thinning and dieback ratings of the same trees made in July of 2009. 
of the injections, the plastic ports (Arborplugs) were extruded (Figure 5b). No weeping, oozing or decay was noted. No structural failures were observed. This study suggests that tree injections are well tolerated in healthy green ash and have a potential role as a tool to protect trees against exotic and destructive pests.

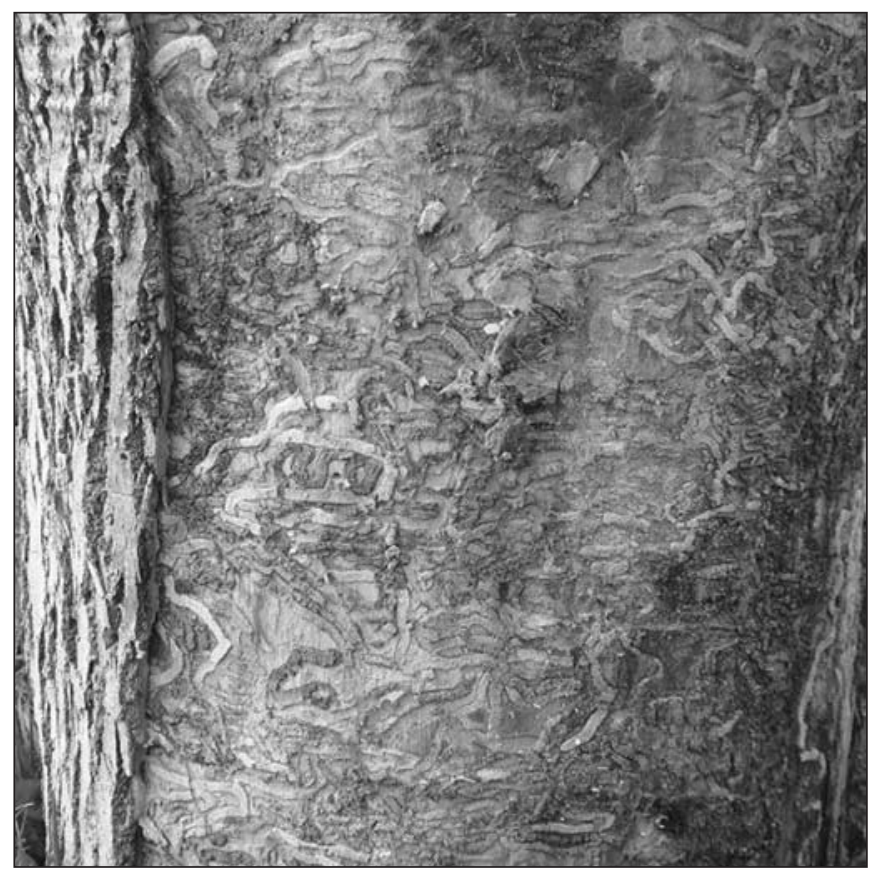

Figure 4. Section of trunk from untreated control tree with bark removed showing extensive tunneling from $E A B$ infestation. EAB larvae feed in the vascular cambium below the bark: left unchecked, they effectively girdled the green ash tree.
Acknowledgments. The authors would like to thank David Smith, East Lansing Forestry Manager, for the permitting of the tree removals, and Jack Barkley and the Ayles Tree Service crew for tree removals. Thanks also to Ian Hudson, Angela Zito, and Chase Boggs-Smitley for data collection and photographic images of tree dissections. The authors also thank Dr. David Cox, Syngenta Crop Protection, for his review and comments.

\section{LITERATURE CITED}

Abacus Concepts. 1991. SuperAnova Berkeley (CA): Abacus Concepts. Abacus Concepts. 1992. StatView Berkeley (CA): Abacus Concepts.

Cappaert, D., D.G. McCullough, T.M. Poland, and N.W. Seigert. 2005. Emerald ash borer in North America: a research and regulatory challenge. American Entomologist 51:152-165.

Chaney, W.R. 1986. Anatomy and Physiology Related to Chemical Movement in Trees. Journal of Arboriculture 12(4):85-91.

Dujesiefken, D., W. Liese, W. Shortle, and R. Minocha. 2005. Response of beech and oaks to wounds made at different times of the year. European Journal of Forest Research 124:113-117.

Ellmore, G.S., W.E. Phair, C. Gill, and D. Skinner. 1988. Fluid Delivery in Injected Ring-porous Trees. Journal of Arboriculture 14(10):233-239.

Esau, Katherine. 1977. Anatomy of Seed Plants. Second Edition. John Wiley and Sons. New York. Santa Barbara. London, Sydney. Toronto. $550 \mathrm{pp}$.

Haack, R.A., E. Jendek, H. Liu, K.R. Marchant, T.R. Petrice, T.M. Poland, and H. Ye. 2002. The emerald ash borer: a new exotic pest in North America. Newsletter Michigan Entomology Society 47:1-5.

Herms, D.A., D.G. McCullough, D.R. Smitley, C.S. Sadoff, R.C. Williamson, P.L. Nixon. 2009. Insecticide Options for Protecting Ash Trees from Emerald Ash Borer. North Central IPM Bulletin 12 pp.

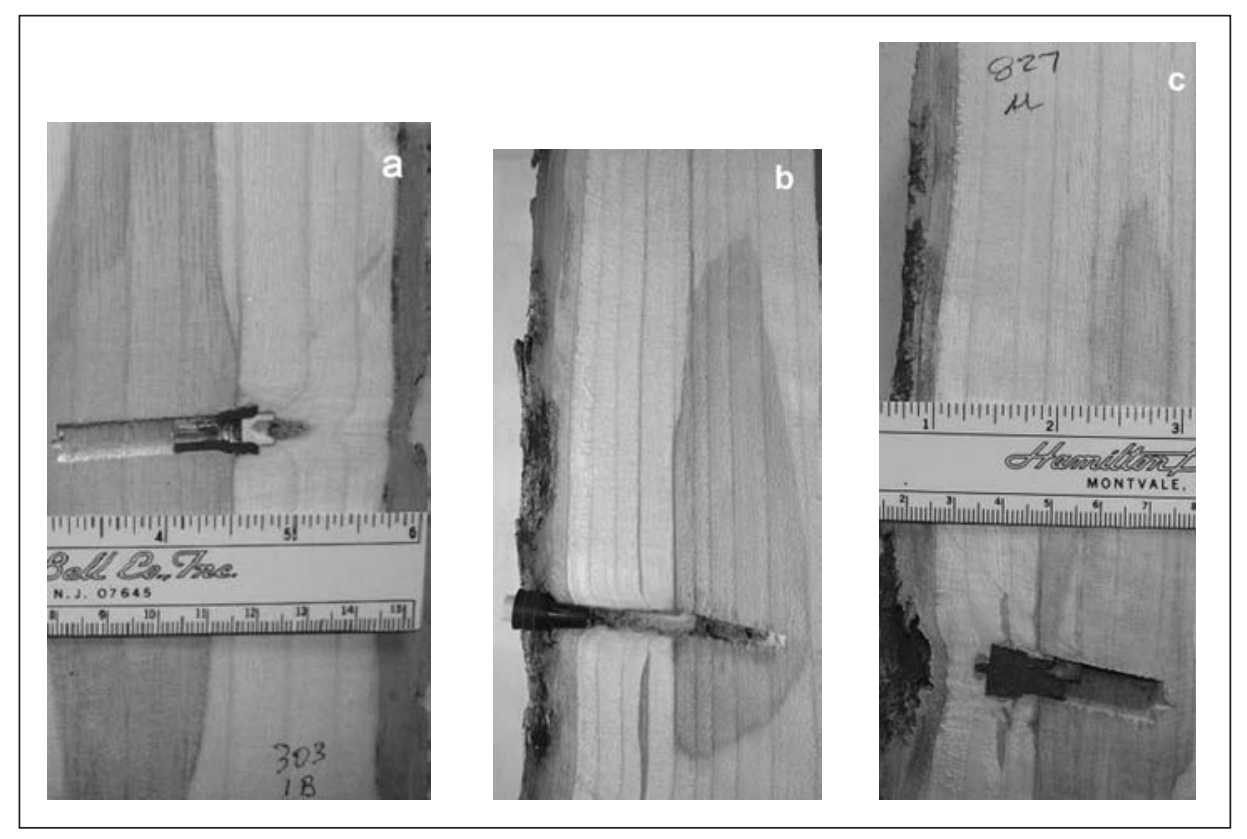

Figure 5. Longitudinal section through injection sites of three healthy trees that were protected from EAB with IMA-jet or TREE-äge. a) Tree felled three years after the trunk injection and the injection plug was encapsulated. b) Tree felled four years after injection and the injection plug was extruded. c) Tree felled three years after trunk injection using the large diameter plug, which was also encapsulated. 


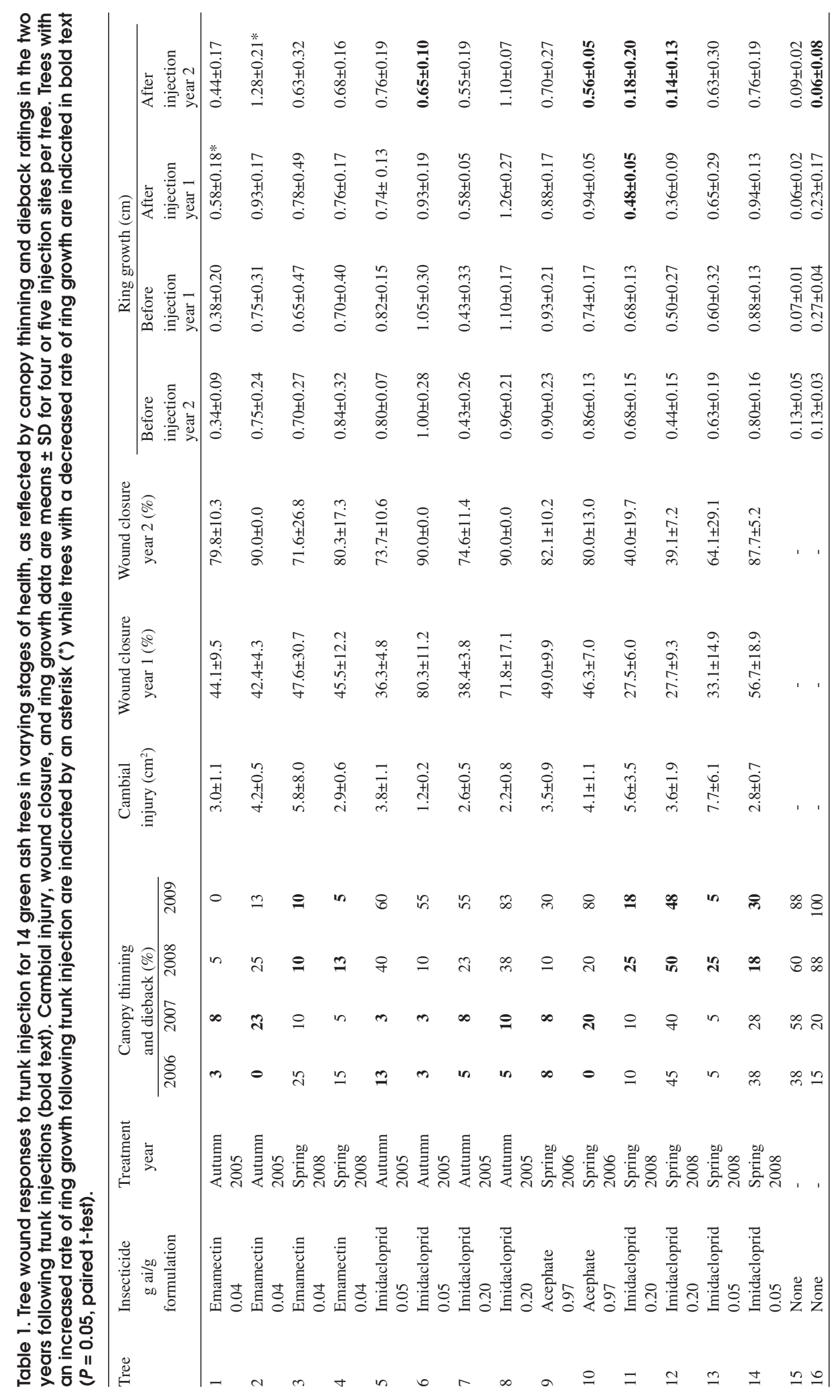


McCullough, D.G., A. Agius, D. Cappaert, T. Poland, D. Miller, and L. Bauer. 2003. Host Range and Host Preference of Emerald Ash Borer. Report. Department of Entomology and Department of Forestry, Michigan State University. USDA Forest Service, North Central Research Station.

McFarlane, D.W., and S.P. Meyer. 2003. Characteristics and distribution of potential ash hosts for Emerald Ash Borer. Department of Forestry, Michigan State University.

Salisbury F.B., and R.V. Parke. 1970. Vascular Plants: Form and Function. Second Edition. Wadsworth Publishing Company, Inc. Belmont CA. 252 pp.

Sanchez-Zamora, M.A., and R. Fernandez-Escobar. 2004. Uptake and distribution of trunk injections in conifers. Journal of Arboriculture 30:73-79.

Shigo, A.L., and H.G. Marx. 1977. Compartmentalization of decay in trees. U.S. Department of Agriculture Forest Service, Agricultural Information Bulletin $405.73 \mathrm{pp}$.

Shigo, A.L., W.E. Money, and D. Dodds. 1977. Some internal effects of Mauget tree injections. Journal of Arboriculture 3:213-220.

Shigo, A.L. 1984. Compartmentalization: a conceptual framework for understanding how trees grow and defend themselves. Annual Review of Phytopathology 22:189-214.

Shigo, A.L. 1991. Modern Arboriculture. Shigo and Trees, Associates. Durham, NH. 423 pp.

Shigo, A.L. 1999. A New Tree Biology: Facts, Photos and Philosophies on Trees and Their Problems and Proper Care. Shigo and Trees, Associates. Durham, NH. 618 pp.

Smith, K.T. 1988. Wounding, compartmentalization, and treatment tradeoffs. Journal of Arboriculture 14:226-229.

Smith, K.T. 2006. Compartmentalization Today. Arboricultural Journal, AB Academic Publishers. Great Britain. 29:173-184.

Smith, K.T., and P.A. Lewis. 2005. Potential concerns for tree wound response from stem injection in: ONKENB, and Reardon R. (Compilers), Proceedings of the Third Hemlock Wooly Adelgid Conference, Asheville, North Carolina, February 1-3, 2005. USDA Forest Service Publication FHTET 2005-01, pp. 173-1 78.

Smitley, D., T. Davis, and E. Rebek. 2008. Progression of ash canopy thinning and dieback outward from the initial infestation of emerald ash borer (Coleoptera: Buprestidae) in Southeast Michigan. Journal of Economic Entomology 101:1643-1650.

Smitley, D.R., J.J. Doccola, and D.L. Cox. 2011. Multiple-year protection of ash trees from emerald ash borer, Agrilus planipennis Fairmaire (Coleoptera: Buprestidae), with a single trunk injection of emamectin benzoate. Arboriculture \& Urban Forestry 37: in press.

Tattar, T.A., and S.J. Tattar. 1999. Evidence of the Downward Movement of Materials injected into Trees. Journal of Arboriculture 25(6):325-332.

Joseph J. Doccola (corresponding author)

Director of Research

Arborjet, Inc.

99 Blueberry Hill Road

Woburn, MA 01801, U.S.

781-935-9070

joedoccola@arborjet.com

David R. Smitley, Ph.D.

Department of Entomology

243 Natural Sciences Building

Michigan State University

East Lansing, MI 48824
Terrance W. Davis

Research Assistant III

Department of Entomology

Michigan State University

John Joseph Aiken

Michigan Representative

Arborjet, Inc.

46565 Garfield Road

Macomb, MI 48044

Peter M. Wild

Consulting Arborist

Arborjet, Inc.

99 Blueberry Hill Road

Woburn, MA 01801, U.S.

Résumé. L'injection par le tronc d'insecticides ou de fongicides systémiques constitue un moyen efficace de gérer les parasites destructeurs chez les arbres, mais plusieurs arboriculteurs sont toujours réticents envers l'injection d'arbres en raison des infections potentielles par des agents pathogènes, des dommages structuraux ou des effets adverses sur la santé des arbres. Les auteurs de l'étude qui suit ont étudié le type de réponse face aux blessures chez le frêne de Pennsylvanie (Fraxinus pennsylvanica Marsh.) durant les deux années suivant l'injection en sectionnant des troncs d'arbre afin d'étudier les indices d'infection associés à ces sites et en colligeant des données annuelles sur la croissance radiale annuelle et le taux de fermeture autour des sites d'injection. Tous les arbres en santé ont compartimenté avec succès les blessures d'injection avec aucun signe de présence d'infection, de carie ou de dommage structural. La fermeture des blessures était positivement corrélée avec la santé des arbres mesurée en fonction de la croissance radiale annuelle.

Zusammenfassung. Die Stamminjektion von systemischen Insektiziden oder Fungiziden ist ein effektiver Weg, destruktive Insekten oder Krankheiten von Bäumen zu begrenzen, aber viele Arboristen sind immer noch zurückhaltend gegenüber Stamminjektionen wegen der potentiellen Gefahr von Infektionen durch Pathogene, strukturelle Schäden oder ungünstige Auswirkungen auf die Baumgesundheit. Die Autoren der vorliegenden Studie untersuchten die Wundreaktionen von Eschen über zwei Jahre nach der Stamminjektion durch eine Sektionierung des Stammes, um nach Hinweisen auf eine durch Injektionen assoziierte Infektion zu suchen und zur Datensammlung von jährlichem radialen Wachstum und der Rate des Wundverschlusses um die Injektionsstelle. Alle gesunden Bäume haben erfolgreich ohne Anzeichen von Infektionen, Fäule oder Strukturschäden um die Injektionsfläche kompartmentalisiert. Der Wundverschluss war positiv mit der Baumgesundheit, gemessen in jährlichem radialen Zuwachs, korreliert.

Resumen. Abstract. La inyección al tronco de insecticidas o fungicidas sistémicos es una forma efectiva de manejar insectos o enfermedades destructivas de los árboles, pero muchos arboristas son aún renuentes a inyectar los árboles debido a la potencial infección por patógenos, daños estructurales, o efectos adversos en la salud del árbol. Los autores del estudio examinaron las respuestas de las heridas de encino verde (Fraxinus pennsylvanica Marsh.) en los dos años siguientes a la inyección al tronco seccionando los troncos de los árboles para mirar la evidencia de la infección asociada con los sitios de inyección, y colectando datos en anillos anuales de crecimiento y tasa de cierre alrededor de los sitios de inyección. Todos los árboles saludables compartimentaron exitosamente las heridas de inyección sin ningún signo de infección, decaimiento, o daño estructural. El cierre de las heridas estuvo correlacionado positivamente con la salud del árbol, medida por el crecimiento radial anual. 